\title{
Forage Standing Crop and Animal Diets Under Rotational vs. Continuous Grazing
}

\author{
STEVEN H. SHARROW
}

\begin{abstract}
Effects of 5-paddock rotational grazing and continuous grazing were monitored in 1977 and 1978 on an annual grass-subclover (Trifolium subterraneum) pasture. More forage was available to livestock under rotational grazing than under continuous grazing during the midspring through late spring period. However, grazing management had little effect upon forage intake by Romney ewes and their lambs during this period. Live weight gains of ewes and lambs were higher under rotational compared with continuous grazing in the spring, perhaps due to an observed increase in subclover, a highly nutritious feed, in diets of sheep grazing rotationally. In contrast to the spring green-feed period, live weight gains of ewes under rotational grazing were lower than those under continuous grazing during the summer dry-feed period. Poor ewe performance on rotationally grazed pasture during the summer period apparently reflects reduced opportunity for dietary selectivity and, therefore, a lower quality diet compared with that available to ewes on continuously grazed pasture.
\end{abstract}

There a re approximately 5 million hectares of hill pasture land in the Pacific Coastal States. Much of this land currently supports annual vegetation because of inherently xeric sites or improper grazing management in the past. Both continuous grazing and a system similar to that proposed for New Zealand hill pastures by Suckling (1965), in which rotational grazing is employed to remove excess dry forage and to control weeds in the summer followed by continuous grazing during the remainder of the year, are common management systems in western Oregon. While little information is available from annual grass-clover pastures, Sharrow and Krueger (1979) have demonstrated that animal performance from improved hill pastures seeded to perennial ryegrass (Lolium perenne-subclover (Trifolium subterraneum) can be increased by employing a rotational grazing scheme.

Many studies comparing rotational grazing to continuous grazing management systems have been conducted during the past 20 years. As a result of these studies, a substantial body of knowledge has been collected from and general management principles proposed for perennial grass swards (Morley 1968; Smetham 1973). However, scant literature is available to directly evaluate applicability of these principles to annual grass-clover swards.

The objective of this study was to compa re forage standing crop, dry matter intake, and diets selected by sheep grazing rotationally to those grazing continuously on an annual grass-subclover pasture under high stocking rates.

\section{Materials and Methods}

The study was conducted on 2 ha of hill pasture located approximately $20 \mathrm{~km}$ north of Corvallis, Ore. Elevation is approximately $100 \mathrm{~m}$. The climate is maritime with cool, rainy winters and warm, dry summers. Mean annual precipitation is $103 \mathrm{~cm}$. Species composition of the pasture prior to grazing in May 1977 was $56 \%$ rattail fescue (Vulpia myuros), 12\% soft chess (Bromus mollis), 25\% subclover (Trifolium subterraneum), and $3 \%$ perennial ryegrass (Lolium perenne) by weight.

Author is associate professor, Oregon State University, Corvallis 97331.

This report is Oregon Agricultural Experiment Station Technical Paper No. 6243.

Manuscript received June 14, 1982.
The original 2-ha pasture was divided into 2 equal parts. One half was continuously grazed throughout the grazing season (approximately April-December). The remaining half was subdivided into 5, 0.2-ha paddocks. Ewes and the lambs consecutively grazed each paddock for 4 days before being moved into the next paddock. Each paddock was thus grazed 4 days and then allowed 16 days to recover before being grazed again. Stocking rate on both continuous and rotational grazing treatments was 12 ewes and their lambs per hectare. Sheep live weights were measured every 2 weeks using a portable livestock scale. Lambs were removed when they ceased to gain weight on pasture (in early summer each year).

A more detailed description of animal management practices and past management of the experimental pastures is provided by Sharrow and Krueger (1979).

Because of the importance of the spring green-feed period to livestock production from annual grass pastures, forage available to and diets selected by sheep were studied during the midspring to early summer period in 1977 and 1978. This period was arbitrarily divided into 3 sections: (1) midspring, the time of rapid vegetative plant growth, (2) late spring, a time when plants were maturing and producing seed and (3) early summer, when plants were drying out and seed was mature.

Forage standing crop and forage disappearance were estimated for each period using the movable cage technique (Brown 1954). Ten $0.1-\mathrm{m}^{2}$ rectangular plots were harvested inside and outside cages on each treatment pasture every 2 weeks. Harvested material was hand sorted, oven dried at $50^{\circ} \mathrm{C}$, and the dry weight of each species was recorded. Forage dry matter intake by livestock was calculated from the difference between caged and uncaged plots on each date using the equation of Linehan et al. (1952). Dietary selectivity was investigated using a relative preference index (Van Dyne and Heady 1965) calculated as: $\%$ of plant in diet $/ \%$ of plant in sward. Data were pooled by period and means compared using Student's $T$ tests.

\section{Results and Discussion}

The rotationally grazed pasture consistently had more total forage available during midspring $(P<.10)$ and late spring $(P<.05)$ periods than did the continuously grazed pasture (Table 1). Once the period of plant growth was over in early summer, the rotational pasture had similar (1977) or less $(P<.05,1978)$ total forage standing crop than the continuously grazed pasture. Herbage consumption, however, did not reflect differences in herbage standing crop between treatments. Wheeler et al. (1962) made a similar observation. They could find no usable relationship between digestible organic matter intake by sheep and forage standing crop from a variety of perennial grass-clover pastures. Arnold and Dudzinski (1967) also noted apparent discrepancies between forage standing crop and expected dry matter intake by sheep. They suggest that intake by ewes is not adequately determined by forage standing crop alone because other factors, such as sward height, affect harvesting of forage by livestock. Forage digestibility and its concomitant effects upon gut fill (Ellis 1978) can also be expected to affect dry matter intake of grazing animals.

The herbage consumption figures reported in Table l exceed the NRC (1975) recommendations for dry matter intake for mainte- 
Table 1. Average herbage standing crop, herbage consumption, and live weight changes of ewes and lambs from pastures grazed continuously (C) or rotationally (R).

\begin{tabular}{|c|c|c|c|c|c|c|c|c|}
\hline \multirow[b]{2}{*}{ Season } & \multicolumn{2}{|c|}{$\begin{array}{c}\text { Average herbage } \\
\text { standing crop (kg/ha) }\end{array}$} & \multicolumn{2}{|c|}{$\begin{array}{c}\text { Herbage consumption } \\
\text { (g/kg body weight/day) }\end{array}$} & \multicolumn{2}{|c|}{$\begin{array}{c}\text { Ewe live weight } \\
\text { change (g/ewe/day) }\end{array}$} & \multicolumn{2}{|c|}{$\begin{array}{c}\text { Lamb live weight } \\
\text { change (g/lamb/day) }\end{array}$} \\
\hline & $\mathrm{C}$ & $\mathbf{R}$ & $\mathrm{C}$ & R & C & $\mathbf{R}$ & C & $\mathbf{R}$ \\
\hline $\begin{array}{l}\text { Midspring } 1977 \\
\text { Late spring } 1977 \\
\text { Early summer } 1977\end{array}$ & $\begin{array}{l}2000 \\
1850 \\
1460\end{array}$ & $\begin{array}{l}2430^{\dagger} \\
2800^{*} \\
1440\end{array}$ & $\begin{array}{l}28 \\
39 \\
23\end{array}$ & $\begin{array}{l}27 \\
37 \\
23\end{array}$ & $\begin{array}{l}-120 \\
-80 \\
-150\end{array}$ & $\begin{array}{c}-90 \\
-20 \dagger \\
-300^{*}\end{array}$ & $\begin{array}{l}90 \\
10\end{array}$ & $\begin{array}{r}170 \dagger \\
70^{\dagger}\end{array}$ \\
\hline $\begin{array}{l}\text { Midspring } 1978 \\
\text { Late spring } 1978 \\
\text { Early summer } 1978\end{array}$ & $\begin{array}{l}1590 \\
2949 \\
2990\end{array}$ & $\begin{array}{l}2550^{*} \\
3620^{*} \\
2180^{*}\end{array}$ & $\begin{array}{l}36 \\
27 \\
32\end{array}$ & $\begin{array}{l}36 \\
31 \\
30\end{array}$ & $\begin{array}{c}260 \\
-80 \\
-100\end{array}$ & $\begin{array}{c}230 \\
-40 \\
-100\end{array}$ & $\begin{array}{l}420 \\
170\end{array}$ & $\begin{array}{l}390 \\
190\end{array}$ \\
\hline
\end{tabular}

$*+$ Continuous differs from rotational grazing treatment $(P<.05, P<.10$ respectively).

nance of ewes (18 $\mathrm{g} / \mathrm{kg}$ body weight/day) in each period both years. However, dry matter intake required by lactating ewes (32 $\mathrm{g} / \mathrm{kg}$ body weight/day) was not met in midspring 1977 on either treatment. Likewise, the $35 \mathrm{~g} / \mathrm{kg}$ body weight/day suggested for growing lambs was not achieved during midspring 1977 or late spring 1978. It appears, therefore, than even with substantial amounts of herbage standing crop, lamb performance may have been limited by insufficient dry matter intake during these periods regardless of grazing management.

Since no meaningful differences were detected in herbage consumption, treatment differences in lamb and ewe weight gains shown in Table 1 likely reflect differences in quality rather than quantity of the diet selected under each treatment. Species composition of the forage available in each pasture is presented in Table 2. In 1977, the only treatment difference detected was a higher $(P<.05)$ subclover content of forage in the rotational grazing system during the midspring period. However, analysis of species composition of the diet selected by rotationally grazing animals (Table 3 ) indicated higher subclover consumption during the mid and late spring periods $(P<.05)$ and a higher intake of forbs during the midspring period $(P<.01)$ of 1977 than occurred under continuous grazing. In addition, soft chess contributed more to the late spring $(P<.05)$ and less to the early summer $(P<.01)$ diet of rotationally grazing animals than to that of ewes and lambs under continuous grazing in 1977. Even though the greater quantity of forage available to ewes and lambs grazing rotationally did not affect their herbage consumption, it apparently allowed them to exercise more dietary selectivity. This aided them in choosing a high quality diet from the larger standing crop of forage available on the rotationally grazed pasture. This supposition is supported by the higher relative preference indices observed for rotational compared with continuous grazing during this period (Table 4). Hamilton et al. (1973) have observed a similar effect of dietary quality, in this case in vitro digestibility, increasing as herbage on offer increases. It is believed that the greater amount of forbs, principally subcover, in the mid and late spring diets of livestock on rotational grazed pastures contributed substantially to the superior weight gains of these animals during the green-feed period.

By the start of the dry-feed period in early summer 1977 selective grazing had removed most forbs from both pastures. Higher consumption of soft chess $(P<.05)$ during the late spring resulted in fewer seedheads, a preferred summer feed, being available to sheep on the rotational pasture. Summer diets of sheep reflected differences in forage standing crop. Approximately $97 \%$ of the forage consumed on both pastures was rattail fescue and soft chess. Forbs contributed little to summer diets of rotationally grazed sheep. The summer diet of sheep on the continuously grazed pasture contained approximately $3 \%$ forbs. The major difference in diets attributable to grazing management during the early summer was a higher proportion of soft chess $(P<.01)$, principally seedheads, in the diets of sheep on continuously grazed pastures. Relative preference indices calculated for rotationally grazing sheep were lower than those for continuous grazing during this period (Table 4). This observation, together with the relatively poor 1977 summer performance of ewes grazing rotationally, lends credence to Heady's (1962) and Barnes' (1977) concern that the concentration of livestock required by rotational grazing systems may depress a nimal performance by reducing their ability to select a high quality diet during some portion of the year.

The spring of 1978 was relatively cool and moist. This favored growth of cool-season forbs such as subclover. Subclover was the highest single element in both forage standing crop and sheep diets

Table 2. Species composition (\% of weight) of herbage available on continuously (C) and rotationally (R) grazed pasture in western Oregon.

\begin{tabular}{|c|c|c|c|c|c|c|}
\hline \multirow[b]{3}{*}{ Species } & \multicolumn{6}{|c|}{ Season } \\
\hline & \multicolumn{2}{|c|}{ Midspring 1977} & \multicolumn{2}{|c|}{ Late spring 1977} & \multicolumn{2}{|c|}{ Early summer 1977} \\
\hline & $\mathrm{C}$ & $\mathbf{R}$ & C & $\mathbf{R}$ & $\mathrm{C}$ & $\mathbf{R}$ \\
\hline Vulpia myuros & 84 & 77 & 86 & 73 & 91 & 90 \\
\hline Bromus mollis & 10 & 12 & 9 & 20 & 9 & 9 \\
\hline Trifolium subterraneum & 3 & $9^{*}$ & 1 & 2 & $\mathrm{~T}$ & $\mathrm{~T}$ \\
\hline Lolium perenne & 1 & $\mathrm{~T}$ & 1 & 1 & 0 & $\mathrm{~T}$ \\
\hline Misc. grass & 1 & $\mathrm{~T}$ & 1 & $\mathrm{~T}$ & $\mathrm{~T}$ & $\mathrm{~T}$ \\
\hline \multirow[t]{3}{*}{ Misc. forbs } & 1 & 2 & 2 & 4 & $\mathbf{T}$ & $\mathbf{T}$ \\
\hline & \multicolumn{2}{|c|}{ Midspring 1978} & \multicolumn{2}{|c|}{ Late spring 1978} & \multicolumn{2}{|c|}{ Early summer 1978} \\
\hline & C & $\mathbf{R}$ & $\mathrm{C}$ & $\mathbf{R}$ & C & $\mathbf{R}$ \\
\hline Vulpia myuros & 38 & 42 & 60 & $34 * *$ & 20 & $71^{* *}$ \\
\hline Bromus mollis & 15 & 15 & 13 & 13 & 70 & $25^{* *}$ \\
\hline Trifolium subterraneum & 42 & 41 & 22 & $49 * *$ & 3 & 2 \\
\hline Lolium perenne & $\mathrm{T}$ & 2 & 1 & 3 & 6 & 0 \\
\hline Misc. grass & $\mathrm{T}$ & $\mathrm{T}$ & 2 & 0 & 1 & 2 \\
\hline Misc. forbs & 1 & $\mathrm{~T}$ & 2 & $\mathrm{~T}$ & $\mathrm{~T}$ & $T$ \\
\hline
\end{tabular}

**:*Continuous differs from rotational grazing treatment $P<.01, P<.05$, respectively. 
Table 3. Species composition (\%) of diets selected by sheep on continuously $(C)$ and rotationally ( $R$ ) grazed pastures in western Oregon.

\begin{tabular}{|c|c|c|c|c|c|c|}
\hline \multirow[b]{3}{*}{ Species } & \multicolumn{6}{|c|}{ Season } \\
\hline & \multicolumn{2}{|c|}{ Midspring 1977} & \multicolumn{2}{|c|}{ Late spring 1977} & \multicolumn{2}{|c|}{ Early summer 1977} \\
\hline & $\mathrm{C}$ & $\mathbf{R}$ & $\mathrm{C}$ & $\mathbf{R}$ & C & $\mathbf{R}$ \\
\hline Vulpia myuros & 84 & 54 & 76 & 35 & 64 & 87 \\
\hline Bromus mollis & 10 & $1 * *$ & 15 & $31^{*}$ & 33 & $12 * *$ \\
\hline Trifolium subterraneum & 6 & $38^{*}$ & 1 & $8^{*}$ & 2 & 0 \\
\hline Lolium perenne & 0 & 1 & 5 & 5 & 0 & $\mathrm{~T}$ \\
\hline Misc. grass & 0 & 1 & 1 & 1 & 0 & 1 \\
\hline \multirow[t]{3}{*}{ Misc. forbs } & $\mathrm{T}$ & 5 & 20 & $2 * *$ & 1 & 0 \\
\hline & \multicolumn{2}{|c|}{ Midspring 1978} & \multicolumn{2}{|c|}{ Late spring 1978} & \multicolumn{2}{|c|}{ Early summer 1978} \\
\hline & C & $\mathbf{R}$ & C & $\mathbf{R}$ & $\mathrm{C}$ & $\mathbf{R}$ \\
\hline Vulpia myuros & 17 & 6 & 52 & $7 * *$ & 19 & $69^{* *}$ \\
\hline Bromus mollis & 12 & 11 & 4 & $\mathbf{T}$ & 66 & $24 \dagger$ \\
\hline Trifolium subterraneum & 69 & 80 & 42 & $92^{* *}$ & 0 & 0 \\
\hline Lolium perenne & 0 & 0 & 0 & 0 & 11 & 0 \\
\hline Misc grass & 0 & 0 & 0 & 0 & 4 & 7 \\
\hline Misc. forbs & 1 & 1 & 2 & 1 & 0 & 0 \\
\hline
\end{tabular}

*** $\dagger$ Continuous differs from rotational grazing treatment $P<.01, P<.05, P<.10$, respectively.

Table 4. Relative preference indices (\% of species in diet/\% of species in sward) for plants in continuously (C) and rotationally (R) grazed pastures in western Oregon.

\begin{tabular}{|c|c|c|c|c|c|c|}
\hline \multirow[b]{3}{*}{ Species } & \multicolumn{6}{|c|}{ Season } \\
\hline & \multicolumn{2}{|c|}{ Midspring 1977} & \multicolumn{2}{|c|}{ Late spring 1977} & \multicolumn{2}{|c|}{ Early summer 1977} \\
\hline & $\mathrm{C}$ & $\mathbf{R}$ & $\mathrm{C}$ & $\mathbf{R}$ & $\mathrm{C}$ & $\mathbf{R}$ \\
\hline Vulpia myuros & 1.0 & 0.7 & 0.9 & 0.5 & 0.7 & 1.0 \\
\hline Bromus mollis & 1.0 & 0.1 & 1.7 & 1.6 & 3.7 & 1.3 \\
\hline Trifolium subterraneum & 2.0 & 4.2 & 1.0 & 4.0 & - & - \\
\hline Lolium perenne & - & - & 5.0 & 5.0 & - & - \\
\hline Misc grass & 一 & - & 1.0 & - & - & - \\
\hline \multirow[t]{3}{*}{ Misc forbs } & - & 2.5 & 0.5 & 5.0 & - & - \\
\hline & \multicolumn{2}{|c|}{ Midspring 1978} & \multicolumn{2}{|c|}{ Late spring 1978} & \multicolumn{2}{|c|}{ Early summer 1978} \\
\hline & $\mathrm{C}$ & $\mathbf{R}$ & $\mathrm{C}$ & $\mathbf{R}$ & $\mathrm{C}$ & $\mathbf{R}$ \\
\hline Vulpia myuros & 0.5 & 0.1 & 0.9 & 0.2 & 1.0 & 1.0 \\
\hline Bromus mollis & 0.8 & 0.7 & 0.3 & 0.1 & 1.0 & 1.0 \\
\hline Trifolium subterraneum & 1.6 & 5.3 & 1.9 & 1.9 & - & - \\
\hline Lolium perenne & - & - & - & - & 1.8 & - \\
\hline Misc. grass & - & - & - & - & 4.0 & 3.5 \\
\hline Misc forbs & 1 & - & 1 & - & - & - \\
\hline
\end{tabular}

during midspring 1978. No major treatment differences $(P>.10)$ were evident in midspring forage standing crop or in the diets selected by sheep. By late spring, however, the rotation pasture contained over twice as much subclover $(P<.01)$ as did the continuously grazed pasture. Sheep diets during this period were also twice as high in subclover $(P<.01)$ under rotational as under continuous grazing. Similar to 1977, sheep diets during the early summer 1978 were almost devoid of forbs. Major dietary elements during this period were rattail fescue and soft chess. Summer diets of sheep in the rotationally grazed pasture were lower in soft chess $(P<.01)$ and higher in rattail fescue $(P<.01)$ than those in the continuously grazed pasture.

\section{Management Implications}

These data suggest that animal performance during the spring green-feed period was largely determined by the amount of subclover present in sheep diets under the 2 treatments examined. Rotational grazing resulted in more subclover on offer to sheep than occurred under continuous grazing. When subclover was plentiful, such as in 1978, little difference in animal performance could be attributed to grazing management. When subclover was scarce, as occurred in 1977 , the additional clover on offer under rotational grazing allowed selection of a diet higher in clover. This was reflected in increased live weight gains of sheep on rotationally grazed, relative to continuously grazed, pasture. Subclover and other annual forbs were largely consumed on both pastures by early summer. Diets of ewes and livestock performance during this period reflected the higher contribution of soft chess, the preferred summer feed, to forage standing crop under continuous compared with rotational grazing.

These observations suggest that rotational grazing can be effective in increasing forage available to livestock and improving animal performance during the green-feed period, when plants are actively growing. During the dry-feed period, however, rotational grazing should be avoided because it tends to suppress dietary selectivity and to reduce animal performance.

\section{Literature Cited}

Amold, G.W., and M.L. Dudzinskl. 1967. Studies on the diet of the grazing animal. II. The effect of physiological status in ewes and pasture availability on herbage intake. Aust. J. Agr. Res. 18:349-359.

Barnes, D.L. 1977. An analysis of rotational grazing on veld. Rhodesia Agr. J. 74:147-151.

Brown, D, 1954. Methods of surveying and measuring vegetation. Commonwealth Bureau of Pastures and Field Crops. Bull. 42. 
Ellis, W.C. 1978. Determinants of grazed forage intake and digestibility. J. Dairy Sci. 61:1823-1840.

Hamilton, B.A., K.J. Hutchinson, P.C. Annis, and J.B. Donnelly. 1973. Relationships between the diet selected by grazing sheep and the herbage on offer. Aust. J. Agr. Res. 24:271-277.

Heady, H.F. 1961. Continuous vs. specialized grazing systems: a review and application to the California annual type. J. Range Manage. 14:182-193.

Linehan, P.A., J. Lowe, and R.H. Stewart. 1952. The out put of pasture and its measurement. J. Brit. Grassld. Soc. 2:73-98.

Morely, F.H.W. 1968. Pasture growth curves and grazing management. Aust. J. Exp. Agr. Anim. Husb. 8:40-45.

National Research Council. 1975. Nutrient requirements of domestic animals, No. 5. Nutrient requirements of sheep. Fifth edition. Nat. Acad. Sci., Nat. Res. Counc., Washington D.C.
Sharrow, S.H., and W.C. Krueger. 1979. Performance of sheep under rotational and continuous grazing on hill pastures. J. Anim. Sci. 49:893-899.

Smetham, M.L. 1973. Grazing management, p. 179-228. In: R.H.M. Langer (editor), Pastures and Pasture Plants. A.H. and A.W. Reed, London.

Suckling, F.E.T. 1965. Hill pasture improvement. New Zealand Dep. Sci. Indust. Res. Unnumbered Rep.

Wheeler, J.L., T.F. Reardon, and L.J. Lambourne. 1962. The effect of pasture availability and shearing stress on herbage intake of grazing sheep. Aust. J. Agr. Res. 14:364-372.

Van Dyne, G.M., and H.F. Heady. 1965. Botanical composition of sheep and cattle diets on a mature annual range. Hilgardia $36: 465-492$. 